\title{
HOUSE OF ROLE AS AN EFFORT TO PROTECT CHILDREN FROM VIOLENCE: AN INDONESIAN PERSPECTIVE
}

\author{
Sholahuddin Al-Fatih ${ }^{1 *}$ \\ 1*Fakultas Hukum, Universitas Muhammadiyah Malang, Indonesia, sholahuddin.alfath@gmail.com \\ (corresponding).
}

\begin{abstract}
This research aims to discuss the children's violence that occur in Indonesia. This research using legal research, namely research conducted to produce arguments, new theories or concepts as a prescriptive in solving the problems faced. This research found that the number of cases of violence against children in Indonesia is very high and tends to increase from year to year. To overcome this, it is necessary to create a role model house, namely a house that involves 5 elements (parents, family, community, government, local and state governments) in fulfilling children's rights to prevent violence.
\end{abstract}

Keywords: house of role; protect; children; violence; human rights

\section{INTRODUCTION}

Indonesia is the fourth largest population in the world after China, India, and the Americas. Indonesia's population reaches $237,641,326$ people (BPS, 2020a), which makes the country has diversity in various dimensions. The diversity can also be found in the age range of the population in Indonesia. The population under 15 years old is $28.9 \%$, the other $66.1 \%$ are people aged $15-64$ years, and the remaining 5\% are elderly residents or over 64 years old (BPS, 2020b).

The high ratio of productive age population (15-64 years) guarantees the availability of human resources that can affect the development and development of a country. However, on the other hand, the ratio of the productive age population is too high is also prone to cause unemployment, limited access to education, violations of human rights (human rights) and several other problems. In fact, the state should guarantee the protection and fulfillment of human rights for all its people, as mandated in Article 28 of the 1945 NRI Constitution.

Article 28 of the 1945 Constitution of the Republic of Indonesia states that, "Freedom of association and assembly, expressing thoughts orally and in writing and so on is determined by law." Furthermore, in Article 28 A-J the state also guarantees the fulfillment of other human rights (Sudrajat, 2011).

The independence of human rights guaranteed in the law results in conflict and violations. Michael Freeman commented on the sharp disparity of human rights concepts with the reality of human rights violations. He said "human rights violations are facts than can be, and sometimes are, best expressed in terms of numbers, but there is uneasy relationship between our knowledge 
of the numbers and our understanding of what they mean" (Freeman, 2004). The state is considered to take too much hegemony over the aspects of humanity hidden behind human rights and cannot control the violations inflicted by society. The government's inability to take pro-people's policies eventually caused some problems in the middle of society



\begin{tabular}{|l|}
\hline Criminality \\
$\square$ Land conflict \\
$\square$ Inheritance, marriage and \\
divorce \\
$\square$ Domestic violence \\
Election disputes \\
$\square$ Abuse of authority \\
$\square$ Ethnic/religious conflict
\end{tabular}

Figure 1. Types of disputes in Indonesia (UNDP, 2014)

From the data above, it can be known that the most common problem is the high level of criminal acts (Erdianti \& Al-Fatih, 2019a). Of the many cases of criminality that exist, children are objects that are very vulnerable to violating their rights. From data received by the Komnas PA (Komisi Nasional Perlindungan Anak/National Commission for Child Protection), in 2012 there were about 10,105,230 children who were the object of crime. A total of 2,673 cases of violence, of which $48 \%$ or 1,075 cases were in the form of sexual violence, 819 cases of physical violence, and 743 cases of psychological violence. A total of 82 percent of violence occurred among the lower middle-class economy.

Violence is considered a very risky act and threatens the future of children (Fatiara, n.d.). The problem is certainly quite worrying, considering that of the total population of Indonesia of $237,641,326$ people, about $34.26 \%$ or $81,415,918$ people are children aged $0-17$ years. Ages $0-17$ fall into the category of children as referred to in article 1 number 1 of Law No. 23 of 2002 on Child Protection.

Legal protection of children is a constitutional right for every Indonesian child. Because children are development capital that will maintain, maintain and develop the results of existing development. Therefore, children need protection in order to ensure the growth and development of physical, mental and social, harmonious and balanced (Gosita, 1999). Several solutions have been tried, both by the government and those who care about children's rights (Erdianti \& AlFatih, 2019b). Such as ratifying the KHA (Konvensi Hak Anak/Convention on the Rights of the Child) through the Presidential Decree No. 36 of 1990, following the declaration of a world fit for children in 2001 to the ratification of Law No. 23 of 2002 on Child Protection.

However, like other legal products, everything seems to have stalled at the implementation stage. So far there have been no comprehensive measures that can provide protection against children from violence. Child-friendly district/city policies supported by the concept of PUHA 
(Pengarusutamaan Hak Anak/Mainstreaming Children Rights) have also not provided encouraging results. It also indicates that the state, government, society and families who are obliged and responsible for the implementation of child protection do not function optimally.

In fact, it is expressly stated in article 28B paragraph (2) of the 1945 NRI Constitution, that every child is entitled to protection from violence, discrimination and guaranteed the fulfillment of his rights by law. Therefore, the author chose the title "House of Role as an Effort to Protect Children from Violence: An Indonesian Perspective."

\section{RESEARCH METHOD}

This research is a type of legal research (Peter Mahmud Marzuki, 2014), namely research conducted to produce arguments, new theories or concepts as a prescriptive in solving the problems faced. The author conducts legal research to examine and provide a systematic explanation of the House of Role as an Effort to Protect Children from Violence: An Indonesian Perspective.

\section{Research Approach}

\section{Conceptual Approach}

According to Peter Mahmud Marzuki, conceptual approach is a method of approach that is done in a way to study the views and doctrines in the science of law. By studying these views and doctrines, researchers will discover ideas that give birth to legal understandings, legal concepts, and legal principles relevant to the issues at hand.

\section{Case Approach}

The case approach is a type of approach that refers to the ratio decidendi, i.e. the legal reasons used by the judge to get to his verdict. In this study, the authors used the approach of cases of violence against children that occurred in Indonesia.

\section{Statutory Approach (Statue Approach)}

The statutory approach is a method of approach that is carried out by analyzing and reviewing all laws and regulations related to and related to the theme or legal issues discussed.

\section{Source of Legal Materials}

This research is sourced from primary legal materials and secondary legal materials. The primary legal material consists of legislation and judge's rulings. While secondary legal material consists of textbooks, legal dictionaries and legal journals.

\section{Legal Materials Search}

The technique of tracing legal materials in this research was carried out through library research. This method is carried out by collecting, studying and reviewing legal materials that have relevance to the themes discussed.

\section{Research Analysis}

Legal material analysis techniques are an important stage in a study. Legal materials that have been collected into classification and analysis materials using prescriptive analysis (Peter Mahmud Marzuki, 2017) techniques aimed at producing arguments, theories or new concepts on the results of research on violence against children that has been done. 
The argument here is done to explain whether the law is true to the facts or legal events of the research. As a prescriptive science, the science of law studies the purpose of law, values, justice, the validity of the rule of law, the concepts of law and the norms of law. Thus, conclusions will be produced in the form of arguments, new theories or concepts related to the role of the house and the idea of legal protection against children from violence based on human rights perspective (Said, 2018).

\section{RESULTS AND DISCUSSION}

\section{Children Law, Child Abuse and Legal Protection: Between Theory and Practices}

\section{The Concept of Children's Law}

A set of laws governing children is referred to as the law of the child. Some of the matters stipulated in the child law include: the child court system, the child as the perpetrator of the crime, the child as the victim, the rights and obligations of the child, child welfare, the appointment and guardianship of the child, child protection, the role and position of the child and so on (Prinst, 2003). While the definition of a child according to Article 1 point 1 of the Law of the Republic of Indonesia Number 23 of 2002 concerning Child Protection, it is stated that the child is a person who is not yet 18 (eighteen) years old, including a child who is still in the womb.

The age limit of the child gives a grouping of a person to be referred to as a child as a form of the child's ability in legal status (Wadong, 2000). Because every child basically needs coaching, special guidance in order to develop their physical, mental and spiritual to the maximum (Wadong, 2000). Children's law guarantees the fulfillment of children's rights, such as (Wadong, 2000):

a. The right to live, grow, develop and participate reasonably in accordance with dignity and humanity;

b. The right to a name as identity and citizenship status;

c. The right to worship according to his religion, thinking, and expression according to his level of intelligence and age, in the guidance of parents;

d. The right to know his parents;

e. The right to obtain health and social security services according to physical, mental, spiritual and social needs;

f. The right to education and teaching;

g. The right to express and be heard;

h. The right to rest and make use of free time;

i. Rights of children with disabilities;

j. The right to protection from discrimination, exploitation, neglect, violence, injustice and other mi wrong behavior;

k. The right to foster parents;

1. The right to freedom.

\section{The Concept of Human Rights in Indonesia}

Children's rights are part of the great concept of human rights. The development of human rights mindset is almost in line with human development itself. In this case, Todung Mulya Lubis (Lubis, 1993) explained that there are four kinds of theories about human rights, namely first, 
natural rights, the view that human rights are rights always owned by man and places based on his destiny as a human being. Second, the positivist theory (positive theory), which holds that the right must be contained in the real law. This theory is deeply influenced by the view of Jeremy Bentham with his utilitarian.

Third, the theory of cultural relativist theory, which holds that human beings are social and cultural interaction and different cultural traditions and civilizations that contain different human perspectives. Fourth, Marxist doctrine and human rights, which hold the view that rights are recognized as individual rights, when they have gained recognition from the state and collectivity.

In Indonesia, the discourse on human rights enforcement began in 1997, when the Komnas HAM (Komisi Nasional Hak Asasi Manusia/National Human Rights Commission) was established. The amendment of the 1945 Constitution is a historical fact and is believed to be the starting point for the repeal of Indonesian democracy based on human rights protection (Muhtaj, 2005). However, strong efforts to defend and protect human rights have not been made to the maximum. Human rights violations are still common, precisely when the state is actively voicing protection of basic human rights.

Human rights often experience reduction and deviation of meaning. Human rights are understood as an absolute right regardless of the importance of the presence of human obligations. It is difficult to understand how the strong push to defend human rights turns out to contain actions that violate human rights itself (Muhtaj, 2009).

\section{Legal Protection Concept}

To fulfill human rights for every citizen, the government needs to create a strong legal protection system. The protection of the law is an act of protecting the subjects of the law with the prevailing laws and regulations and its implementation can be imposed with a sanction (Agustina, 2010). In other words, the protection of law as an illustration of the function of law, namely the concept where the law can provide justice, order, certainty, benefit and peace.

Protection law for the community is distinguished by two kinds, namely: preventive legal protection and repressive legal protection. In preventive legal protection, the public is given the opportunity to file an objection (inspraak) before a government decision gets a definitive form. Protection of this type of law for example before the government sets a rule/decision, the people can object, or be asked for their opinion on the plan of the decision. Thus preventive legal protection aims to prevent disputes.

While repressive legal protection is legal protection that is done by applying sanctions against perpetrators in order to restore the law to its true state (Kasenda, 2015). This type of protection is usually done in court. Repressive legal protection aims to resolve the dispute. In fact, the protection of the law has to do with how the law can provide justice.

According to Philipus M. Hadjon, Indonesia as a legal state must provide legal protection to its citizens based on or in accordance with Pancasila (Hadjon, 1987). Therefore, the protection of law in a country based on Pancasila, the most important principle is the principle of harmony based on family. The concept of legal protection ensures that every citizen obtains human rights and treatment without discrimination in the community.

\section{Violence Against Children}


Terry E. Lawson, classifies child abuse into four forms, namely: emotional abuse, verbal abuse, physical abuse, and sexual abuse. Meanwhile, Suharto that cited by Abu Hurarerah grouped child abuse as follows (Huraerah, 2007):

a. Physical child abuse, is torture, beating, and child abuse, with or not using certain objects, resulting in physical injury or death to the child.

b. Psychological child abuse, including sedation, the delivery of harsh and dirty words, exposing books, images, and pornographic films to children.

c. Sexual child abuse, can be in the form of social precontact treatment between children and larger people (through words, touch, visual images, exhibitionism), as well as direct sexual contact between children and adults (incest, rape, sexual exploitation).

d. Social child abuse, can include child abuse and child exploitation.

According to Komnas PA data on violence against children in 2011 reached 2,509 cases, with $52 \%$ of them being the category of sexual violence (Perlindungan Anak, 2014). In 2012, child abuse increased by nearly 130 percent. The number of child abuse in 2012 reached 2,637 cases, with $62 \%$ of them being sexual violence. Meanwhile, KPAI during 2012 received 273 complaints of child abuse cases, with the number of sexual violence as many as 98 cases or an increase of 2030\% from 2011 (KPAI, 2014).

IMMC (Indonesia Media Monitoring Center) version, 26\% of violence against children occurs in the social sphere, $14 \%$ of the legal sphere, $11 \%$ of education and health, $2 \%$ of the economy and $1 \%$ of religion. And when viewed from the perpetrators, $70 \%$ of the perpetrators are from outside and the remaining $30 \%$ are the closest people in the family (IMMC, 2014). From the small picture, it can be seen clearly that the problem of violence against children is not a small problem. If not treated immediately, this act of violence against children will be a time bomb.

\section{Current Child Protection}

This eligible district or city was born through Law No. 23 of 2002 on Child Protection. Child-friendly regency or city is a district/city that has a development system based on children's rights through the integration of commitments and resources of the government, community and business that are planned thoroughly and sustainably in policies, programs and activities to ensure the fulfillment of children's rights.

To make an area as a child-friendly district/city, must be fulfilled several indicators, including the fulfillment of five basic rights of the child, such as civil rights and child freedom, family environment, basic health and welfare, education and special protection.

Although it has been regulated in a Ministerial Regulation, but the implementation of the idea of child-friendly districts/cities is still very lacking. One of the things that is an obstacle to the realization of child-friendly districts/cities in some areas is the pattern of poor urban planning, so that it is not able to provide supporting facilities for the growth and development of children (MenegPP, 2014).

Besides child-friendly district/city, there was an idea of PUHA was born through Law No. 23 of 2002 on Child Protection. PUHA is a child protection strategy by integrating children's rights into every development activity.

PUHA concept is implemented integrated since the preparation of planning, budgeting, implementation, monitoring, and evaluation of various laws and regulations, policies, programs, and activities by applying the principle of best interests for children. However, the PUHA concept 
is still not able to contribute the maximum to the government's efforts in order to fulfill children's rights.

\section{House of Role as an Effort to Protect Children from Violence}

Nowadays, sexual violence against children has been a concern international community. Its hidden, sustainable, and very dangerous nature, cause this crime needs to be dealt with seriously (Windari \& Syahputra, 2020). Some of idea has been released to protect children's rights from violence, but it's too far away to gain best solutions. In this paper, the author analyzed one model named the house of role to solve it problems.

The house of role is one of the instruments that are simultaneously used with an integrated model with PUHA to realize child-friendly districts/cities. In juridical norm, it belongs to UUD NRI 1945, Convention on Children Rights that ratified by Presidential Decree Number 36 of 1990, Law Number 39 of 1999 concerning Human Rights, Law number 35 of 2014 concerning amendments to Law Number 23 of 2002 concerning Child Protection and Law number 23 of 2004 concerning Abolition Domestic Violence (Fitriani, 2016)(Kobandaha, 2017).

The house of role is closely related to the five pillars, namely: parents, family, community, government, local and state governments. the roles of each of these stakeholders will be explained in the following diagram:



Figure 2. The House of Role Models

In the role of the house, the government is asked to make regulations that prevent violence against children, including providing severe penalties for perpetrators of violence against children. Then, at the regional government level, the government is asked to realize the creation of childfriendly districts/cities, even if necessary, to make it to the lowest level, namely to sub-districts, villages and even RW and RT that are child-friendly. If the regulations and products have been 
made and provided by the government, the next role is played by the community, family and parents

In this context, the role of the house is intended as a place to protect the fulfilment of children's rights, ensure their growth and development, supervise them and keep them away from violence. There will be regular gatherings to monitor whether the smallest level, namely the parents, has been able to guarantee the fulfillment of the basic rights of children, prevent violence and report if there is an alleged violence. So, through this role house, ideal conditions will be created to fulfill children's rights in accordance with the mandate of the Indonesian constitution and ensure the fulfillment of children's rights throughout Indonesia.

\section{CONCLUSION}

Based on the above discussion, it can be concluded that the number of cases of violence against children in Indonesia is very high and tends to increase from year to year. To overcome this, it is necessary to create a role model house, namely a house that involves 5 elements (parents, family, community, government, local and state governments) in fulfilling children's rights to prevent violence. However, further research needs to be made to measure the effective role played by each of these stakeholders.

\section{DAFTAR PUSTAKA}

Agustina, K. (2010). Perlindungan Hukum. Jakarta.

BPS. (2020a). Official News Statistics May 5, 2020,. Retrieved from https://www.bps.go.id/website/materi_ind/materiBrsInd-20200505115439.pdf

BPS. (2020b). SOCIAL STATISTICAL ANALYSIS: Demography Bonus and Economic Growth.

Erdianti, R. N., \& Al-Fatih, S. (2019a). Fostering as an Alternative Sanction for Juveniles in the Perspective of Child Protection in Indonesia. JILS (Journal of Indonesian Legal Studies), 4(1), 119-128. https://doi.org/10.15294/JILS.V4I01.29315

Erdianti, R. N., \& Al-Fatih, S. (2019b). Mewujudkan Desa Layak Anak Sebagai Bentuk Perlindungan Hukum Terhadap Anak Di Indonesia. Justitia Jurnal Hukum, 3(2), 305-318. Retrieved from http://journal.um-surabaya.ac.id/index.php/Justitia/article/view/3648/2361

Fatiara, N. (n.d.). KPAI: 153 Kekerasan Anak Terjadi di Sekolah, Pelakunya Mayoritas Guru kumparan.com. Retrieved June 8, 2020, from https://kumparan.com/kumparannews/kpai153-kekerasan-anak-terjadi-di-sekolah-pelakunya-mayoritas-guru-1sXmURDSLII

Fitriani, R. (2016). Peranan Penyelenggara Perlindungan Anak Dalam Melindungi Dan Memenuhi Hak-Hak Anak. Jurnal Hukum Samudra Keadilan, 11(2), 250-358. Retrieved from https://www.ejurnalunsam.id/index.php/jhsk/article/view/42/23

Freeman, M. (2004). Human Rights; An Interdisciplinary Approach. Cambridge University Press.

Gosita, A. (1999). Masalah Perlindungan Anak. Bandung: Akademindo. 
Hadjon, P. (1987). Perlindungan Hukum bagi Rakyat Indonesia. Surabaya: Bina Ilmu.

Huraerah, A. (2007). Kekerasan Terhadap Ana. Bandung: Nuansa.

IMMC. (2014). Analisa Hari Anak'.

Kasenda, D. G. (2015). Ganti Rugi Dalam Pengadaan Tanah Untuk Kepentingan Umum. Jurnal Morality, 2(2), 1-21.

Kobandaha, M. (2017). PERLINDUNGAN HUKUM TERHADAP ANAK KORBAN KEKERASAN DALAM RUMAH TANGGA DALAM SISTEM HUKUM DI INDONESIA. Jurnal Hukum Unsrat, 23(8), 82-91. Retrieved from https://ejournal.unsrat.ac.id/index.php/jurnalhukumunsrat/article/view/15070/14635

KPAI. (2014). KPAI Prihatin Kasus Pemerkosaan Anak'.

Lubis, T. M. (1993). In Search of Human Rights; Legal-Political Dilemmas of Indonesia's New Order, 1966-1990. Jakarta: Gramedia Pustaka Utama.

MenegPP. (2014). Glossary Perlindungan Ana.

Muhtaj, M. El. (2005). Hak Asasi Manusia dalama Konstitusi Indonesia. Jakarta: Prenada Media.

Muhtaj, M. El. (2009). Dimensi-dimensi HAM, Mengurai Hak Ekonomi, Sosial dan Budaya. Jakarta: Rajawali Press.

Perlindungan Anak, K. (2014). Komnas PA: Kasus Kekerasan Anak Naik 130 Persen. Retrieved from Viva News website: http://nasional.news.viva.co.id/news/read/379793-komnas-pa-kasus-kekerasan-anak-naik-130-persen

Peter Mahmud Marzuki. (2014). Penelitian Hukum. Jakarta: Kencana Prenada Media Group.

Peter Mahmud Marzuki. (2017). Penelitian Hukum: Edisi Revisi (Cetakan ke). Retrieved from https://books.google.co.id/books?id=CKZADwAAQBAJ\&printsec=frontcover\&dq=Marzu ki,+Peter+Mahmud,+(2014),+Penelitian+Hukum,+Cetakan+ke-

9,+Jakarta:+Kencana+Media+Group.\&hl=id\&sa=X\&ved=0ahUKEwiNlIjqlbTpAhXWWis KHWktCXAQ6AEIMjAB\#v=onepage \&q\&f=false

Prinst, D. (2003). Hukum Anak Indonesia (Citra Aditya Bhakti, Ed.). Bandung.

Said, M. F. (2018). PERLINDUNGAN HUKUM TERHADAP ANAK DALAM PERSPEKTIF HAK ASASI MANUSIA. JCH (Jurnal Cendekia Hukum), 4(1), 141-151. https://doi.org/10.33760/jch.v4i1.97

Sudrajat, T. (2011). Perlindungan Hukum terhadap Hak Anak sebagai Hak Asasi Manusia dalam Perspektif Sistem Hukum Keluarga di Indonesia. Kanun: Jurnal Ilmu Hukum, 3(2), 111132.

UNDP. (2014). Indonesia : Governance and Decentralization Survey (GDS). Retrieved from UNDP website:

https://www.id.undp.org/content/indonesia/en/home/ourwork/democraticgovernance/overv 
iew.html

Wadong, M. H. (2000). Pengantar Advokasi dan Hukum Perlindungan Anak. Jakarta: Radja Grafindo Persada.

Windari, R., \& Syahputra, A. (2020). Menakar Aspek Kemanfaatan dan Keadilan Pada Sanksi Kebiri Kimia Terhadap Pelaku Kekerasan Seksual Anak Di Indonesia. Soumatera Law Review, 3(2), 1-9. https://doi.org/10.22216/soumlaw.v3i1.5433 